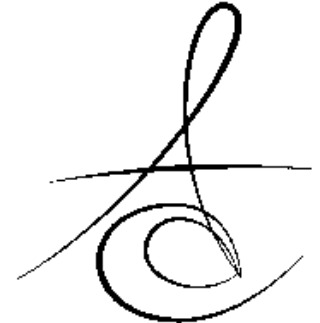

Makale Kodu/Article code: 1841

Makale Gönderilme tarihi: 02.09 .2014

Kabul Tarihi: 12.10 .2014

\section{DİŞ PROTEZ TEMİZLİK ÜRÜNLERİNİN BAKTERİYOLOJİK AKTİVİTELERİNİN ARAŞTIRILMASI}

\section{AN INVESTIGATION OF THE BACTERIOLOGICAL ACTIVITY OF DENTURE CLEANSING PRODUCTS}

\author{
Doç.Dr. Kazım Serhan AKŞİT* \\ Dr. Gamze MANDALI*
}

\author{
Doç.Dr. Yaşar NAKİPOĞLU** \\ Uzm Dr. Gülşen GÜNEL** \\ Prof.Dr. Bülent GÜRLER ${ }^{* *}$
}

\section{ÖZET}

Amaç: Diş protezlerinin temizliği ve dezenfeksiyonuna gereken önemin verilmemesi, ağız içi enfeksiyonlarla birlikte endokardit gibi sistemik enfeksiyonlara da yol açabilir. Bu tür enfeksiyonların önlenmesi veya azaltılabilmesi için uygun protez kaide materyalinin seçimi ile birlikte protezlerin temizlenmesi ve dezenfeksiyonunu sağlayabilen etkin bir ürünün belirlenmesi büyük önem taşımaktadır. Araştırmamızda, halen Türkiye'de diş protezlerinin temizliği ve dezenfeksiyonlarında kullanılan çeşitli ürünlerin antibakteriyel etkinliklerinin araştırılması amaçlanmıştır.

Materyal ve Metod: Araştırmamızda, 3 adet alkalen peroksit grubu efervesan diş protez temizleme tableti (Fittydent (Matilek-Avusturya), Corega tabs (GlaxoSmithKline, İrlanda), Protefix (Queisser pharma, Almanya)) ile 2 adet dezenfektan solüsyonun (Curaprox BDC 105 (haftalık kullanımlı) (Swiss Premium Oral Care, İsvec), Curaprox BDC 100 (Günlük kullanımlı) (Swiss Premium Oral Care, İsveç)); dört tip protez kaide materyali deney örneklerine (Vertex (Vertex-Dental B.V, Hollanda), Rodex (Rodont, İtalya), Meliodent (Kulzer, Almanya), Molloplast-B (Detax, Almanya)) bulaştırılmış Staphylococcus aureus ATCC 6538, Pseudomonas aeruginosa NCTC 6749 ve Bacillus subtilis var. niger ATCC 9372 bakteri suşlarına karşı etkinlikleri üretici firma tarafından önerilen sürelerde incelenmiştir.

Bulgular: Denenen ürünlerin tamamının S.aureus ATCC 6538 bakteriye karşı; $\% 100$ oranında etkili olduğu belirlenmiștir. P.aeruginosa NCTC 6749 sușuna karșı ise; Fittydent'in, 30 dakika temas süresinde, Corega tabs ve Protefix tabletlerinin $15^{\prime}$ er dakikada, Curaprox BDC $105^{\prime}$ in ise, 1. ve 7.gün sonunda da 6 saatlik temas süresinde aynı etkiyi (\%100) gösterdiği belirtilmiștir. Curaprox BDC 100'ün ise, 5 dakika temas süresinde \% 93-100 arasında etkinlik sağladığı gözlenmiștir. B.subtilis var. niger ATCC 9372 bakteri sporu üzerinde; Curaprox $\mathrm{BDC} 105^{\prime}$ in 1. ve 7.gündeki solüsyonlarının $\% 99$ oranında etkili olduğu, diğer ürünlerin ise temas süre ve protez maddelerine göre Fittydent'in; \%97-98, Corega tabs' in ; \%91-99, Protefix'in; \%68-95, Curaprox BDC 100 ' ün; \%72-99 gibi değişen oranlarda dezenfeksiyon sağladığı belirlenmiştir.

Sonuç: Farklı tip diş protez kaide maddeleri üzerinde temizlik ve dezenfeksiyon ürünlerinin etkinliklerinin ortamda bulunan bakterilere göre çok değişken olduğu, protez kaide maddesi tipinin ise dezenfeksiyon üzerinde bir etkisinin olmadığı gözlenmiştir. Protezlerin her gün temizlenmesinin ve dezenfeksiyonunun potansiyel patojen bakteriyel kontaminasyonunu önlemek için etkili bir yöntem olduğu sonucuna varılmıştır.

Anahtar sözcükler: Diş protezi, temizlik, dezenfeksiyon

\section{ABSTRACT}

Aim: The unsufficient cleaning and disenfection of the dentures not only lead to intra-oral infections but also to systemic infections such as endocarditis, which might be life threatening. To prevent or reduce such infections, selection of appropriate denture base material and effective denture cleaning or disinfecting preparations are very important. In our study, we aimed to investigate the antibacterial activity of cleansing and disinfectant preparations currently use in Turkey.

Material and Method: In our study, the antibacterial activity of 3 alkaline peroxide type cleaning denture effervescent tablets (Fittydent (Matilek-Austria), Corega tabs (GlaxoSmithKline, Ireland), Protefix (Queisser pharma, Germany) frequently use in our country and 2 disinfectant solutions (Curaprox BDC 105 (weekly use) (Swiss Premium Oral Care, Sweden), Curaprox BDC 100 (daily use) (Swiss Premium Oral Care, Sweden), were tested against four types of denture base material samples (Vertex (Vertex-Dental B.V, Netherlands), Rodex (Rodont, Italy), Meliodent (Kulzer, Germany), Molloplast-B (Detax, Germany)) contaminated with Staphylococcus aureus ATCC 6538, Pseudomonas aeruginosa NCTC 6749 and Bacillus subtilis var. niger ATCC 9372 at the contact times advised by the manufacturers. Result: It was determined that all of the preparations were found to be $100 \%$ effective against S.aureus ATCC 6538 strain. Fittydent at 30 minutes, Corega tabs and Protefix tablets at 15 minutes of each, and Curaprox BDC 105 at 6 hours in the solutions prepared in the 1.st and the end of the 7.th days, were have the same activity $(100 \%)$ against P.aeruginosa NCTC 6749 strain.Otherwise, Curaprox BDC 100 at 5 minutes contact time was found $93-100 \%$ effective against the same strain. The sporicidal activity of the Curaprox BDC 105 against B.subtilis var. niger ATCC 9372 at 6 hours contact times in the solutions prepared in the 1.st and the end of the 7.th days, were found to be $99 \%$, whereas the activity of the rest of the products were varied depending on the contact time and denture base material and differed between $97-98 \%$ of Fittydent ,91-99\% of Corega tabs , $68-95 \%$ of Protefix, $72-99 \%$ of Curaprox BDC 100.

Conclusion: The effect of denture base materials on the cleaning and disinfection were very variable according to the kinds of bacteria present in the test environment and have not shown to be differed depending on the type of denture base material. Daily cleaning or disinfection of the dentures are an effective way to prevent bacterial contamination with potential pathogens .

Key words: Denture, cleaning, disinfection

\footnotetext{
İstanbul Okmeydanı Ağız ve Diş Sağlığı Hastanesi Protetik Diş Tedavisi Kliniği

**istanbul Üniversitesi İstanbul Tıp Fakültesi Tıbbi Mikrobiyoloji Anabilim Dalı
} 


\section{GİRİ}

Protetik apareylerin gözenekli yapısı, yüzeylerindeki girinti ve çıkıntılar, diş araları, kroşe vb. komponentleri, polimerizasyon, tesviye-cila işlemlerindeki hatalar sonucunda oluşabilecek küçük çizikler, çukurcuklar ve mikroporoziteler besin ve mikroorganizma birikimi için elverişli alanlar oluşturmaktadır ${ }^{1-4 .}$

Protezlerin yapımı ve tamir işlemleri sırasında; kullanılan çeşitli malzemeler (möl-mölet, zımpara, cila fırçaları),materyaller (alçı-pomza vb) ve pomza karışımını yapmak için kullanılan su; potansiyel patojen mikroorganizmaların, havaya dağılmalarına, personelin ellerine, cihazlara bulaşmasına neden olurlar. Sonuçta laboratuvar çalışanları, diş hekimi, dişhekimi yardımcıları ve hastalar arasında potansiyel bir çapraz enfeksiyon riski ortaya çıkar. ${ }^{3,5-7}$

Yapılan mikrobiyolojik incelemelerde; protez üzerindeki bakteri plağının 1 mg'ında yaklaşık 2 milyondan fazla bakteri bulunur, bunlardan Streptococcus mutans, Streptococcus sanguis , Lactobacillus spp., Beta ve D grubu streptokoklar, Fusobacterium türleri, Klebsiella pneumoniae, Enterobacter cloacae, Pseudomonas stutzeri, Staphylococcus aureus, Escherichia coli, alfa ve gama hemolitik streptokoklar, stafilokoklar, mikrokok türleri, difteroidler, Bacillus, Neisseria ve Candida türlerinin varlığına rastlanmıştır ${ }^{3,6,8,9}$. Protezlerin temizliğinde; mekanik ve kimyasal yöntemler kullanılmaktadır.,3,5,10-12-17 Mekanik yöntemler arasında; protezlerin fırça yardımıyla temizlenmesi, protez temizleme pat ve tozları (zirkonyum, Cakarbonat, Ca-fosfat esaslı) diş macunları (Bofors vb), ultrasonik veya sonik temizleyici cihazlar, mikrodalga fırınlarının kullanılması sayılabilir1,11, 12, 14-20. Kimyasal yöntemler olarak ise; alkalen peroksitler, alkalen hipokloritler, seyreltik organik ve inorganik asitler, dezenfektanlar, enzimler olarak gruplandırılan değişik kimyasal ajanlar kullanılmaktadır. 1,2,5,12,15-18,21,22

Alkalen peroksit esaslı sıvı ve efervesan tip protez temizleyici maddeler arasında; Efferdent, Polident, Mersene, Denalan, Kleenite, yeni Kleenite, Bonyplus, Steradent isimli preparatlar bulunmakta$\mathrm{d}_{1} \mathrm{r}^{1,4,5,8,15,16,20,23,24}$. Bu preparatlar sodyum perborat veya perkarbonat gibi oksijen çıkaran veya yüzey gerilimini azaltmak amacıyla trisodyum fosfat gibi alkalen deterjan içeren maddelerdir. Bu eriyiklerden çıkan oksijen kabarcıklarının hafifçe tutunan kirlerin üzerinde mikro-mekanik bir temizleme işlevi yaptığı düşünülmektedir ${ }^{12,18}$. Bu grup temizleyicilerin protez yüzeyindeki ağır kirleri temizlemekte yetersiz kaldıkla$\mathrm{ri}^{1,15,16}$, etkili olabilmeleri için protezlerin kimyasal solüsyonda birkaç saat ya da bir gece bırakılmalarının gerektiği belirtilmektedir ${ }^{1,12}$.

Alkalen hipoklorit tipi protez temizleyicilerin tartarları eritemediği ancak tartarın üzerinde toplandığı organik matriksi eriterek oluşumunu inhibe ettikleri bildirilmektedir ${ }^{1,2,12,18}$. Literatürde dezenfeksiyon amaçIı olarak en çok kullanımına rastlanılan farklı konsantrasyon ve temas süreleri ile Na-hipoklorit solüsyonlarıdır $^{2,3,5,16,21,25,26}$. Ayrıca; \%5'lik hidroklorik asit, \%1525 konsantrasyondaki fosforik asit, \%5'lik asetik asit ve benzoik asit ${ }^{12,13,18} \% 0.4-1^{\prime}$ lik potasyum permanganat $^{2}$, \%2'lik gluteraldehit ${ }^{21}$, klorin dioksit ${ }^{3}, \% 0.2^{\prime}$ lik klorheksidin glukonat ${ }^{5}$, farklı tipte enzimler içeren solüsyonlar ${ }^{9,12}$, \%5 Deconex, \% 3.5'luk Savlex ${ }^{27}$ ve Grotonat Bohrerbad ${ }^{11}$ 'da dezenfeksiyon amaçlı olarak kullanılmaktadır.

Araştırmamızda; farklı tip protez kaide materyalleri (Vertex,Rodex,Meliodent,Molloplast-B)'nin dezenfeksiyonunda; kimyasal yöntemler arasında yer alan ve ülkemizde sıklıkla kullanılan alkalen peroksit grubu Fittydent, Corega tabs, Protefix protez temizleme tabletleri ile Curaprox BDC 105 (haftalık kullanım solüsyonu) ve Curaprox BDC 100 (günlük kullanım solüsyonu)'nun antibakteriyel etkinliğini belirlemek amaçlanmıştır.

\section{MATERYAL VE METOD MATERYAL}

\section{A. Protez temizliğinde ve dezenfeksiyonunda kullanılan preparatlar :}

Araştırmamızda 3 alkalen peroksit grubu protez temizleyici tablet ve 2 dezenfektan solüsyon olmak üzere toplam 5 antibakteriyel preparat kullanılmıştır. $\mathrm{Bu}$ tablet ve solüsyonların adları, üretici firmaları ve kullanım şekilleri aşağıda belirtilmiştir.

1. Fittydent cleansing tablets, alkalen peroksit grubu protez temizleme tableti-efervesan tip-(temas süresi: $30 \mathrm{dk}$ ) (Fittydent INT'L GMBH, Matilek, Avusturya)

2.Corega tabs denture cleanser, alkalen peroksit grubu protez temizleme tableti-efervesan tip-(temas süresi:15 dk) (GlaxoSmithKline, İrlanda)

3.Protefix, alkalen peroksit grubu protez temizleme tableti-efervesan tip-(temas süresi: $15 \mathrm{dk}$ ) (Queisser pharma, Almanya)

Bu tabletler ayrı ayrı $50 \mathrm{ml}$ steril distile suya atılarak günlük solüsyon hazırlanmıştır.

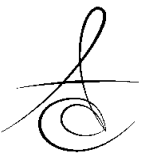


4. Curaprox BDC 105-(uzun süreli haftalık kullanımlı hazır dezenfektan solüsyon),(temas süresi: 6 saat), (Swiss Premium Oral Care, İsveç) (dezenfektan solüsyon; kullanılmaya başlandıktan sonra dezenfektan özelliği ve etkinliğini 1 hafta boyunca sürdürmektedir)

5. Curoprox BDC 100-(kısa süreli günlük kullanımlı hazır dezenfektan solüsyon), (temas süresi; $5 \mathrm{dk}$ ) (Swiss Premium Oral Care, İsveç).

\section{B. Akrilik protez kaide ve yumuşak akrilik deney örnekleri:}

Vertex (Vertex-Dental B.V,Hollanda), Rodex (Rodont,Srl Milan, İtalya), Meliodent (Heraeus Kulzer GmbH. Grüner Weg 11,D-63450 Hanau, Almanya) akrilik protez kaide materyalleri ve silikon esaslı bir yumuşak astar maddesi Molloplast-B (Detax,GmbH \& Co KG D-76275 Ettlingen,Almanya)' den olmak üzere yaklaşık $10 \mathrm{~mm}$ çapında ve $4 \mathrm{~mm}$ kalınlığında dairesel tabletler şeklinde hazırlanmıştır. Her temas süresi için biri kontrol (sadece steril distile suyla muamele edilmiştir) olmak üzere 3 akrilik kaide ve bir yumuşak madde toplam 5 ayrı örnek kullanılmıştır. Tüp örnekler otoklavda $121^{\circ} \mathrm{C}^{\prime}$ de 15 dakikada steril edilmiştir.

\section{Nötralizan madde:}

Antibakteriyel aktiviteyi nötralize etmek için kullanılmıştır. Bunun için lesitin $\% 0.07$ ve Tween 80 $\% 0.5$ oranında triptik soy buyyon besiyerinde hazırlanmış ve $4.5^{\prime}$ er $\mathrm{ml}$ şeklinde deney tüplerine dağıtılarak $121^{0} \mathrm{C}$ de 15 dakika steril edilmiştir.

\section{Kullanılan bakteri suşları:}

Dezenfektan aktivite ölçümü için; önerilen vejetatif bakterilerden S aureus ATCC 6538 ve Pseudomonas aeruginosa NCTC 6749, sporlu bakterilerden ise; Bacillus subtilis var. niger ATCC 9372 suşları kullanılmıştır.

\section{YÖNTEM}

Çalışmamızda, Türk Standartları Enstitüsü'nün (TSE) önerdiği yöntemler modifiye edilerek uygulanmıştır ${ }^{28-29}$. Vejetatif bakterilerin 24 saatlik ve sporlu bakteri suşunun bir haftalık kültüründen $0.5 \mathrm{Mc}$ Farland bulanık tüpüne göre bakteri süspansiyonları hazırlanmıştır. Bu süspansiyon yaklaşık $10^{8} \mathrm{cfu} / \mathrm{ml}$ bakteri içermektedir. Bu süspansiyonlar $1 / 10$ oranında steril tuzlu su (\%0.85 $\mathrm{NaCl})$ ile seyreldikten sonra her üç bakteri süspansiyonundan ayrı ayrı $90 \mathrm{~mm}$ çapında steril plastik Petri kutularına $20 \mathrm{ml}$ aktarılmıştır. Protez kaide maddesi deney örnekleri bu bakterilerle bulaştırımış ve kurumaya bırakılmıştır. Daha sonra $20 \mathrm{ml}$ temizleyici veya dezenfektan solüsyonları içeren steril
Petri kutularına atılarak temas süreleri başlatılmıştır. Her sürenin sonunda deney örnekleri alınarak nötralizör madde içeren deney tüplerine konulmuştur. Nötralizörler 30'ar saniye 3 kez Vorteks cihazı ile karıştırıldıktan sonra 5 dk oda Isısında bekletilmiştir. Daha sonra bu nötralizör maddelerden $1 \mathrm{ml}$ alınarak $9 \mathrm{ml}$ steril tuzlu su ile seyreltilmiştir. Aynı deneylere paralel olarak temizleyici ve dezenfektan solüsyonu yerine steril distile su ile aynı aşamalar kontrol amacıyla tekrarlanmıştır. Tüm nötralizörlü ve seyreltilmiş nötralizörlü tüplerden $0.01 \mathrm{ml}$ alınarak triptik soy agar besiyerlerine (Oxoid, İngiltere) ekim yapılmıştır. Kültürler $35^{\circ} \mathrm{C}$ de 48 saat bekletilmiştir. Deneyler, birden fazla tekrarlanarak elde edilen ortalama sayılar kabul edilmiştir.

Kontrol $(K)$ ve Test $(T)$ kültürlerinde üreyen koloniler sayılarak ( $\mathrm{n}$ ) aşağıdaki formüle göre temizleyici/dezenfektan solüsyonların bakterilere karşı etkinliği yüzde olarak hesaplanmıştır. ${ }^{28,29}$

\% azalma: Tn/ Kn X 100

\section{BULGULAR}

Çalışmamızda kullanılan alkalen peroksit tip protez temizleme tabletleri ile günlük ve haftalık dezenfektan solüsyonların firmalar tarafından önerilen temas sürelerinde tamamının S.aureus ATCC 6538 bakteri suşuna karşı \%100 etkili olduğu belirlenmiştir. P.aeruginosa NCTC 6749 bakteri suşuna karşı protez temizleme tabletleri ve dezenfektan solüsyonlar \%93100 arasında etkinlik göstermiş, en düşük etkinlik Curaprox BDC 100 " günlük" dezenfektanın 5 dakika temas süresinde Meliodent deney örneğinde gözlenmiş (\%93)'tir. B.subtilis var.niger ATCC 9372 sporlu bakteriye karşı en iyi sonuç Curaprox BDC 105 "haftalık" dezenfektan solüsyon ile Corega tabs protez temizleme tableti (\%99 etkinlik)'nde saptanmıştır. Protez kaide maddelerinin temizlik ve dezenfeksiyona etkisinin ise ortamda bulunan bakteriye göre çok değişken olduğu; S.aureus ATCC 6538 suşunda protez kaide maddeleri arasında herhangi bir fark gözlenmez iken, P.aeruginosa NCTC 6749 suşunda \%0.5-7 ve B.subtilis var.niger ATCC suşunda ise \%1-33 oranında etkilediği saptanmıştır. Ancak bu dört farklı tip protez örnekleriyle etkinlik yüzdelerinde küçük farklar olsa bile, protez kaide materyeli cinsi ve özelliklerinin protez temizleme tablet ve solüsyonlarının antibakteriyel etkinliğinde bir rolü olmadığı sonucuna varılmıştır (Tablo 1 ). 
Tablo 1. Diş protez temizlik ürünlerinin antibakteriyel etkinliklerinin sonuçları.

\begin{tabular}{|c|c|c|c|c|c|c|c|c|c|c|c|c|}
\hline \multirow[t]{2}{*}{$\begin{array}{l}\text { Kullanılan dezenfektan } \\
\text { preparatları }\end{array}$} & \multicolumn{4}{|c|}{$\begin{array}{c}\text { S.aureus ATCC } 6538 \\
\text { ( } \% \text { azalma })\end{array}$} & \multicolumn{4}{|c|}{ 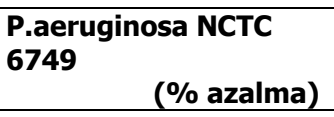 } & \multicolumn{4}{|c|}{ 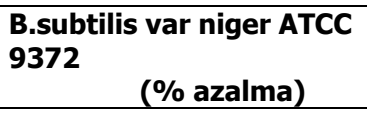 } \\
\hline & 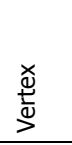 & 㱟 & 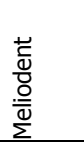 & $\begin{array}{l}\frac{\infty}{1} \\
\frac{1}{n} \\
\frac{0}{0} \\
\frac{0}{0} \\
\frac{\overline{0}}{\Sigma}\end{array}$ & 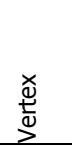 & 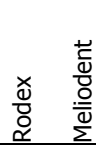 & $\begin{array}{l}\frac{\infty}{4} \\
\frac{1}{\frac{\pi}{0}} \\
\frac{0}{\overline{0}} \\
\sum\end{array}$ & & 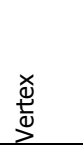 & 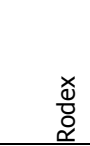 & 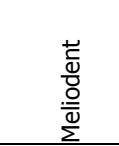 & $\begin{array}{l}\frac{\infty}{4} \\
\frac{i}{\frac{\pi}{0}} \\
\frac{0}{\overline{0}} \\
\sum\end{array}$ \\
\hline $\begin{array}{l}\text { Fitty dent : alkalen peroksit tip } \\
\text { protez temizleme tableti } \\
\text { Uygulama formülü: } 1 \text { tablet/50 ml } \\
\text { steril distile su, } \\
\text { Temas süresi: ( } 30 \text { dakika) }\end{array}$ & 100 & 100 & 100 & 100 & 100 & 100 & 100 & 100 & 97.8 & 98.83 & 98.67 & 98.83 \\
\hline $\begin{array}{l}\text { Corega tabs: alkalen peroksit tip } \\
\text { protez temizleme tableti } \\
\text { Uygulama formülü: } 1 \text { tablet/50 ml } \\
\text { steril distile su } \\
\text { Temas süresi: (15 dakika) }\end{array}$ & 100 & 100 & 100 & 100 & 100 & 100 & 100 & 100 & 91.72 & 99 & 99 & 99 \\
\hline $\begin{array}{l}\text { Protefix: alkalen peroksit tip protez } \\
\text { temizleme tableti Uygulama } \\
\text { formülü: } 1 \text { tablet/ } 50 \text { ml steril } \\
\text { distile su } \\
\text { Temas süresi: ( } 15 \text { dakika) }\end{array}$ & 100 & 100 & 100 & 100 & 100 & 100 & 100 & 100 & 90 & 88.57 & 95 & 68.57 \\
\hline $\begin{array}{l}\text { Curaprox BDC 105: Haftalık protez } \\
\text { temizleme solüsyonu } \\
\text { Temas süresi: (6 saat) } \\
\text { 1.gün } \\
\text { 7.gün }\end{array}$ & $\begin{array}{l}100 \\
100\end{array}$ & $\begin{array}{l}100 \\
100\end{array}$ & $\begin{array}{c}100 \\
100\end{array}$ & $\begin{array}{c}100 \\
100\end{array}$ & $\begin{array}{l}100 \\
100\end{array}$ & $\begin{array}{l}100 \\
100\end{array}$ & $\begin{array}{c}100 \\
100\end{array}$ & $\begin{array}{l}100 \\
100\end{array}$ & $\begin{array}{l}99 \\
99\end{array}$ & $\begin{array}{l}99 \\
99\end{array}$ & $\begin{array}{l}99 \\
99\end{array}$ & $\begin{array}{l}99 \\
99\end{array}$ \\
\hline $\begin{array}{l}\text { Curaprox BDC } 100: \text { Günlük } \\
\text { kullanım protez temizleme } \\
\text { solüsyonu Temas süresi: } 5 \text { dakika }\end{array}$ & 100 & 100 & 100 & 100 & 100 & 100 & 93 & 100 & 99 & 84.29 & 72.57 & 93.48 \\
\hline
\end{tabular}

\section{TARTIŞMA}

Protetik apareylerin yapımı ve uzun süreli kullanımında enfeksiyon riski bulunmaktadır. Bu nedenle protezlerin kullanımı sürecinde mutlaka sterilizasyon, dezenfeksiyon işlemlerine dikkat edilmesi ve bazı koruyucu önlemlerin alınması toplum sağlığı açısından büyük önem taşımaktadır 4, 5, 10.

Protezlerin temizliğinde etkili ve yeterli tek bir temizleyici madde veya yöntem önerebilmek mümkün değildir. Çünkü çeşitli temizleyicilerin etkinliğini karşılaştıran çalışmalarda farklı sonuçlar bildirilmiştir. Bunun nedeni araştırmalarda uygulanan metodolojilerin standart olmaması ya da yöntemlerin farklılığıdır. Üretici firmalar genellikle $40-50{ }^{\circ} \mathrm{C}$ de $15-20$ dakika süre ile protezlerin temizleyici solüsyona bırakılmasını önermektedirler. Ancak çeşitli çalışmalarda bu sürenin yeterli olmadığı görülmüştür. Bu nedenle hem üretici firma önerilerine göre hem de gece boyunca temizleyici ajanlarla etkileşime bırakılmaya dayalı çalışmalar yapılmıştır ${ }^{4}$.
$\mathrm{Bu}$ görüşten hareketle araştırmamızda; halen ülkemizde protez temizliğinde sıklıkla kullanılan Fittydent, Corega tabs, Protefix protez temizleme tabletleri ile yeni kullanıma sunulan Curaprox BDC 105 (haftalık kullanımlı) ve Curaprox BDC 100 (kısa süreli günlük kullanımlı) hazır dezenfektan solüsyonların protez temizliği ve dezenfeksiyonundaki başarı oranları ve antibakteriyel etkinlikleri değerlendirilmeye çalışılmıştır.

Araştırmamızda; Fittydent protez temizleme tableti (temas süresi:30 dk) bütün akrilik ve yumuşak astar maddesi deney örneklerinde \%100'e varan bir dezenfeksiyon etkinliği göstermiştir. Literatür incelemelerimizde; Fittydent protez temizleme tableti ile yapılmış invitro araştırmaya rastlanılmamıştır.

Araştırmamızda; Corega tabs protez temizleme tableti (temas süresi: $15 \mathrm{dk}$ ), tüm akrilik deney örneklerinde ortalama \%99' a varan bir dezenfeksiyon etkinliği göstermiştir. Literatür incelemelerimizde; Corega tabs protez temizleme tableti ile yapılan çalışmalarda; Akşit ve ark. ${ }^{11}$ tüm vegetatif ve sporlu bakterilere karşı \% 100 etkinliği olduğunu gözlemlemişlerdir. De Freitas Fernandes ve ark. ${ }^{30}$, poliamid reçine

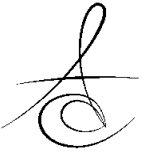


üzerinde şekillenmiş olan bakteri filmleri üzerinde protez temizleyicilerin etkinliğini değerlendirmek amacıyla bir çalışma yapmışlar, akrilik örnek olarak PMMA (Acron MC) ve poliamid reçine (Flexite MP), dezenfektan solüsyon olarak ise enzimatik bir temizleyici olan Polident, Corega tabs ve \% $0.5 \mathrm{Na}$ hipoklorit kullanmışlardır. Sonuç olarak, bütün dezenfektan solüsyonların bakteri suşları üzerinde yüksek etkinlik gösterdiğini ileri sürmüşlerdir. Tüm bu bulgular bizim araştırmamızdaki bulguları da destekler niteliktedir.

Araştırmamızda kullandığımız Protefix protez temizleme tableti (temas süresi: $15 \mathrm{dk}$ ) vegetatif bakterilere karşı \% 100 bir etkinlik göstermiştir. Sporlu bir bakteri suşu olan B.subtilis var. niger ATCC 9372'ye karşı ise tüm akrilik deney örneklerinde \% 88-\%95 arasında bir antimikrobiyal etkinlik sağlanırken, yumuşak astar maddesi Molloplast-B üzerindeki etkinlik \%69 oranında gerçekleşmiştir. Literatür incelemelerimizde; Protefix ile yapılmış araştırmaya rastlanılmamıştır.

Alkalen peroksit benzer tip protez temizleme tabletleri ile yapılan araştırmaları gözden geçirdiğimizde; Tarbet ve ark. ${ }^{23}$, protez temizliğinde etkinlik açısından 2 adet temizleyici tablet solüsyonunu (Efferdent-Polident) ve diş macunu ile fırçalama yöntemlerini değerlendirmişler, macun ile fırçalamanın 12 haftalık period sonunda plakların ortadan kaldırımasında daha etkin olduğunu, tabletlerin ise protezlerin beyazlatılması işleminde gerekli olduğu sonucuna varmışlardır. Chan ve ark. ${ }^{19}$, hareketli protezler üzerindeki bakteri plaklarının uzaklaştırılması ve bakterilerin öldürülmesi amacına yönelik olarak yaptıkları araştırmalarında, Efferdent-Extra protez temizleyici tabletin mekanik bir temizleme yöntemi olan diş macunu ile fırçalama yöntemine oranla daha üstün bir performans gösterdiğini ileri sürmüşlerdir. Glass ve ark. ${ }^{31}$, S.aureus, P.aeruginosa ve B.cereus bulaştırılmış yumuşak astar maddeli protezler ve sert kaide maddeli protezlerin dezenfeksiyonunda medikal tabletleri kullanmışlar, S.aureus ve P.aeruginosa eleminasyonunda başarılı olmuşlardır. Sert kaideli protezlerde ise; S.aureus, P.aeruginosa ve B.cereus bakterilerde azalmalar görülmüştür. Sonuç olarak medikal tablet yoluyla dezenfeksiyon sonucunda belirli mikroorganizma tiplerinde başarılı olunduğu gözlenmiştir. Drake ve ark. ${ }^{8}$, S.mutans üzerinde Efferdent ve Super-strength Polident'in tam etkili olduğunu bildirmişlerdir.
Protezlerin dezenfeksiyonunda; protez temizleyici ajanlarla birlikte mekanik temizleme yöntemlerinin de kullanılmasının gerektiği belirtilmektedir. Gornitsky ve ark. ${ }^{24}$, uzun süreli hastanede tedavi gören ve hastalıklarından dolayı protezlerinde yeterli temizliği yapamayan geriatrik hastalar üzerinde yaptıkları çalışmada; kimyasal protez temizleyici tabletler olarak Denture Brite, Polident ve Efferdent'in dezenfeksiyon etkisini araştırmışlar, Candida spp. ve S.mutans suşları üzerinde protez temizleme tabletleri açısından bir üstünlük olmadığını ifade etmişlerdir. Paranhos ve ark. ${ }^{20}$, akrilik reçine örneklerinde şekillenmiş farklı mikrobiyal film tabakaları üzerinde Bonyplus tableti-5 dk bekletme, 20 sn süreyle Dentu kreme ile fırçalama ve her iki yöntemin kombinasyonu etkinliğini değerlendirmişlerdir. Elde ettikleri sonuçlara göre mikrobiyal suşların tipine bağlı olarak farklı etkinlik görüldüğünü, kimyasal, mekanik ve kombine metod uygulamalarının S.aureus, S.mutans ve P.aeruginosa üzerinde koloni sayılarının azaltılmasında etkin olduğunu gözlemişlerdir.

Araştırmamızın sonuçlarına göre de, her üç protez temizleme tabletinin tüm akrilik ve yumuşak astar maddesi deney örnekleri üzerindeki vegetatif bakterilere karşı \%100 oranında etkili olduğu, sporlu bakterilere karşı ise \%99'a yakın bir etkinlik gösterdiği saptanırken, sadece Protefix protez temizleme tabletinin, sporlu bir bakteri olan B.subtilis var. niger ATCC 9372 'ye karşı yumuşak astar maddesi deney örneklerinde \%69'luk bir mikrobiyal azalma sağladığı gözlenmiştir.

Protezlerin ve yumuşak astar maddelerinin temizliği ve dezenfeksiyonunda; Corega tabs protez temizleme tableti $15 \mathrm{dk}$ temas süresi ile en iyi antimikrobiyal aktiviteyi göstermiştir. Ancak her üç protez temizleme tabletinin de aynı amaca yönelik olarak güvenle kullanılabileceği, koku ve tat problemlerinin olmadığı, ergonomik kullanımlı oldukları, özellikle Fittydent ve Protefix protez temizleyici tabletlerin bazı bakteriler üzerindeki başarısını artırmak ve tam \% 100 etkinlik sağlamak amacıyla mutlaka mekanik temizleme yöntemlerinden de yararlanılmasının gerektiği unutulmamalıdır.

Araştırmamızda protez temizliği ve dezenfeksiyonundaki etkinliği ilk defa değerlendirilen Curaprox BDC 105 (temas süresi: 6 saat) ve Curaprox BDC 100 (temas süresi:5 dk), tüm vejetatif bakterilerde $\% 100$ 'e yakın bir dezenfeksiyon etkinliği göstermiştir. Sporlu 
bakteri B.subtilis ATCC 9372'ye karşı ise en etkili sonuç Curaprox BDC 105'te minimum 6 saat temas süresi ile elde edilmiş ve bu solüsyonun etkinliği 1 hafta boyunca devam etmiştir. Diğer dezenfektan solüsyon Curaprox BDC 100 ise B.subtilis var. niger 9372 bakteri üzerinde $5 \mathrm{dk}$ temas süresi ile akrilik deney örneklerinin cinsine göre \%72-99 arasında değişen bir antimikrobiyal etkinlik göstermiştir.

Literatür incelemelerimizde; araştırmamızda kullandığımız dezenfektan solüsyonlar ile ilgili herhangi bir çalışmaya rastlanılmamıştır. Değişik dezenfektan solüsyonlarla yapılan mikrobiyolojik araştırmalarda ise; Akşit ve ark. ${ }^{11}$, Grotonat Bohrerbad ve Deconex Dental BB'nin vegetatif bakterilere karşı \%100, B.subtilis KUEN 1481'e karşı ise \%93-100 oranında etkinlik gösterdiğini bildirmişlerdir.

Dezenfektan solüsyonlar içerisinde en etkili olanının farklı konsantrasyonlarda hazırlanan $\mathrm{Na}$ hipoklorit solüsyonları olduğu belirtilmektedir 3, 5, 12,13, $16,18,21,25,26$. Ancak bu tip protez temizleyicilerin de ucuz olması avantajına karşın ${ }^{26}$, tad ve koku problemlerinin olması ${ }^{2}$ protezlerde ağarmaya neden olmaları 12,,32, metal komponenti olan protezlerde kararma ve korozyon oluşturmaları, 2,18,22 nedeniyle kullanımları tercih edilmemektedir. Yılmaz ve ark. ${ }^{27}$, dört yumuşak astar maddesi (Tempo, İmmediate, Flexacryl Saf, Ufi Gel P) üzerinde uygulanan 4 değişik dezenfektan solüsyonun (\%5 Deconex, \%3.5 Savlex,\%2 ve \%5.25 dilue sodyum hipoklorit) etkisini araştırmış, bütün dezenfektanların mikroorganizmalar üzerinde etkili olduğunu ve sayılarını azalttığını, etkinliğin artması için protezlerin solüsyon içerisinde bekleme sürelerinin de artırılması gerektiğini bildirmişlerdir.

Araştırmamızda, Curaprox BDC 105; minimal 6 saat temas süresi ile kullanımda en başarılı antimikrobiyal etkinliği göstermiş olup, aynı etkinliğini bir hafta boyunca sürdürmüştür. Diğer dezenfektan solüsyon Curaprox BDC 100 ile vegetatif bakterilerde \%100'e yakın etkinlik sağlanırken, Sporlu bakteride daha az etkili(\%72-99) bulunmuştur. Temas süresi artırılırsa daha iyi sonuçların alınabileceği düşünülmektedir.

Sonuç olarak protezlerin ve yumuşak astar maddelerinin temizliği ve dezenfeksiyonunda; araştırmamızda kullandığımız bütün dezenfektan solüsyonların etkin olduğu, koku ve tat problemlerinin olmadığı, ergonomik oldukları ve rahatlıkla kullanılabilecekleri gözlenmiştir. Yine de dezenfeksiyon işlemlerinde; 6 saat temas süresi ile Curaprox BDC 105, biolojik temizlik etkinliğinin hafta boyunca sürmesi nedeniyle tercih edilebilir.

\section{KAYNAKLAR}

1. Ausburger $\mathrm{RH}$, Elahi JM. Evaluation of seven proprietary denture cleansers.J.Prosthet Dent 1982;47:356-8.

2. Backenstose WM, Wells JG. Side effects of immersion type cleansers on the metal components of dentures. J Prosthet Dent 1977;37:615-21.

3. Bell JA, Brockmann SL, Feil P,Sackuvich DA. The effectiveness of two disinfectants on denture base acrylic resin with an organic load. J Prosthet Dent 1989;61:580-3.

4. Dikbaş $\dot{\mathrm{I}}$, Köksal T. Hareketli protezlerin temizlenmesinde ve dezenfeksiyonunda kullanılan maddeler ve yöntemler. Hacettepe Dişhek Fak Derg 2005;29:16-27

5. Akgök V, Güzel KG, Gül K. Protezlerden bakterilerin izolasyonu ve bu bakterilere çeşitli dezenfektan maddelerin etkisi. Diş Hek Derg 19931994;17:242-8.

6. Assery M, Sugrue C, Graser GN, Eisenberg AD. Control of microbial contamination with commercially available cleaning solutions. J Prosthet Dent 1992;67:275-7.

7. Akpınar Y.Z, Uzun I.H, Yılmaz B, Tatar N, Protetik Tedavilerde Çapraz Enfeksiyon Kontrolü, Atatürk Üniv Diş Hek Fak Derg 2013;supp 7:142-9.

8. Drake D, Wells J, Ettinger R. Efficacy of denture cleansing agents in an in vitro bacteria-yeast colonization model. Int J Prosthodont 1992;5:21420.

9. Nakamoto K, Tamamoto M, Hamada T. Evaluation of denture cleansers with and without enzymes against candida albicans.J Prosthet Dent 1991;66:792-5.

10. Akşit KS, Ünalan F, Gürler B, Nakipoğlu Y, Beyli MS. Pomza tozundan kaynaklanan çapraz bulaşmanın önlenmesi üzerine mikrodalga enerjisi vew dezenfektan solüsyonların etkisi. İ Ü Diş Hek Fak Derg 1994; 28:237.

11. Akşit K.S, Ünalan F, Gürler B, Beka H, Dikbaş İ. Akrilik protez kaide maddeleri ve Molloplast-B'nin dezenfeksiyonunda kullanılan çeşitli yöntemlerin değerlendirilmesi, Ankem Derg 1995;9(1): 79-84.

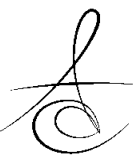


12. Budtz-Jorgensen E. Materials and methods for cleaning dentures. J Prosthet Dent 1979; 42:61963.

13. Lambert JP, Koldstad R. Effect of benzoic aciddetergent germicide on dentine-borne Candida albicans. J Prosthet Dent 1986;55:699-700.

14. Gwinnett AJ, Caputo L. The effectiveness of ultrasonic denture cleaning: A scanning electron microscope study. J Prosthet Dent 1983;50: 20.

15. Dills SS, Olshan AM, Goldner S, Brogdon C. Comparison of the antimicrobial capability of an abrasive paste and chemical-soak denture cleaners. J Prosthet Dent 1988;60:467-70.

16. Moore TC, Smith DE, Kenny GE. Sanitization of dentures by several denture hygiene methods.J Prosthet Dent 1984;52:158-63.

17. Rohrer MD, Bulard RA.: Microwave sterilization. JADA 1985;110:194.

18. Neill DJ. A study of materials and methods employed in cleaning dentures. $\mathrm{Br}$ Dent J 1968; 124: 107-15.

19. Chan EC, Iugovaz I, Siboo R, et al. Comparison of two popular methods for removal and killing of bacteria from dentures. J Can Dent Assoc 1991; 57:937-9.

20. Paranhos HF, Silva-Lovato $\mathrm{CH}$, de Souza RF, et al. Effect of three methods for cleaning dentures on biofilms formed in vitro on acrylic resin.J Prosthodont 2009;18:427-31.

21. Pavarina $A C$, Pizzolitto $A C$, Machado $A L$, Vergani $\mathrm{CE}$, Giampaolo ET. An infection control protocol .Effectiveness of immersion solutions to reduce the microbial growth ondental prostheses .J Oral Rehabil 2003;30:532-6.

22. Taylor VE, Jordan MF.Denture corrosion. Report of a case. Br Dent J 1967;2:399.

23. Tarbet WJ, Axelrod S, Minkoff S, Fratarcangelo PA. Denture cleansing:a comparison of two methods. J Prosthet Dent 1984;51:322-5.

24. Gornitsky M, Paradisl I, Landaverde G, Malo AM, Velly AM. A clinical and microbiological evaluation of denture cleansers for geriatric patients in longterm care institutions.J Can Dent Assoc 2002; 68:39-45.

25. Da Silva FC, Kimpara ET, Mancini MN, Balducci I, Jorge AO, Koga-Ito CY. Effectiveness of six different disinfectants on removing five microbial species and effects on the topographic characteristics of acrylic resin. J.Prosthodont 2008 Dec 17:627-33.

26. Rudd RW, Senia ES, McCleskey FK, Adams ED Jr. Sterilization of complete dentures with sodium hypochlorite. J Prosthet Dent 1984;51:318-21.

27. Yılmaz H, Aydın C, Bal BT, Özçelik B. Effects of disinfectants on resilient denture-lining materials contaminated with Staphylococcus aureus, streptococcus sobrinus, and Candida albicans. Quintessence Int 2005;36:373-81.

28. 28.Türk Standardları Enstitüsü (TSE), TS EN 14561: Çhemical disinfectants and antiseptics quantitative carrier test for the evaluation of bactericidal activity for instruments used in the medical area (2006).

29. Türk Standardları Enstitüsü (TSE), TS 6776 European Standard EN 14347 Chemical disinfectants and antiseptics - Basic sporicidal activity - Test method and requirements (phase 1)(2005).

30. De Freitas Fernandes FS, Pereira-Cenci T, Da Silva WJ, Filho AP, Straioto FG, Del Bel Cury AA. Efficacy of denture cleansers on candida spp.biofilm formed on polyamide and polymethyl methacrylate resins. J Prosthet Dent 2011;105 51-8.

31. Glass RT, Bullard JW, Conrad RS, Blewett EL. Evaluation of the sanitization effectiveness of a denture-cleaning product on dentures contaminated with known microbial flora. An in vitro study. Quintessence Int 2004;35: 194-9.

32. Ünlü A, Altay OT, Şahmalı S. The role of denture cleansers on the whitening of acrylic resins. J Int Prosthodont 1996;9:266-70.

\section{Yazışma Adresi:}

Doç.Dr. Kazım Serhan Akşit

İstanbul Okmeydanı Ağız ve Diş Hastalıkları Hastanesi, Darülaceze cad, Gürsel mah, Kağıthane-Okmeydanı-İstanbul.

Telefon:212-3201043(Dahili:1285-1244)

GSM) 532-3660148

Fax numarası: 212-3204105

E-mail: aksitkserhan@gmail.com 